\title{
7: 72942807-72981505
}

National Cancer Institute

\section{Source}

National Cancer Institute. 7: 72942807-72981505. NCI Thesaurus. Code C45139.

Physical location of LIMK1_Gene 